\title{
STABILNOST GOZDNIH POVRŠIN V SLOVENIJI KOT KRITERIJ KRAJINSKE PESTROSTI IN OBSTOJNOSTI
}

\section{THE STABILITY OF FOREST AREAS IN SLOVENIA AS A CRITERION OF LANDSCAPE DIVERSITY AND DURABILITY}

\author{
Janez PIRNAT ${ }^{1}$, Andrej KOBLER ${ }^{2}$ \\ (1) Univerza v Ljubljana, Biotehniška fakulteta, Oddelek za gozdarstvo in obnovljive gozdne vire, Večna pot 83, SI-1000 Ljubljana, \\ Slovenija \\ (2) Gozdarski Inštitut Slovenije, Večna pot 2, SI-1000 Ljubljana, Slovenija
}

\begin{abstract}
IZVLEČEK
Stabilnost notranjega okolja gozdov je pomemben kazalec biotske pestrosti na krajinskem nivoju, ko se odločamo o tem, ali bi določene gozdove lahko izkrčili. Zaradi tega smo se odločili, da ocenimo stabilnost notranjega gozdnega okolja v Sloveniji med letoma 1975 in 2012, saj so nam na voljo primerljivo dovolj natančni podatki o gozdni maski za teh 38 let.

Štiri vrste sprememb pokrovnosti z gozdom (stabilni negozd, krčitve, zaraščanje in stabilni gozd) pojasnjujemo z empiričnim modelom v obliki odločitvenega drevesa, ki upošteva nadmorsko višino, naklon terena, talni tip, oddaljenost vsake celice na rastrski karti od gozdnega roba v izhodiščnem letu, oddaljenost vsake celice na rastrski karti od najbližjega naselja v izhodiščnem letu. Pojasnjevalne modele smo zgradili po metodi strojnega učenja (Quinlan, 1986) z orodjem See5 (www.rulequest. com). Natančnost izbranega modela je znašala 74,65 \%. V letu 2012 so stabilni gozdovi, katerih površina se od leta 1975 ni spreminjala, pokrivali 53 \% Slovenije. Izmed vseh spremenljivk najbolje pojasnjujeta spremembo rabe začetna oddaljenost od gozdnega roba in deloma naklon terena. Oddaljenost od naselij in nadmorska višina nimata opaznega vpliva.
\end{abstract}

Ključne besede: stabilnost notranjega okolja, prvobitnost gozdov, Slovenija, spremembe pokrovnosti

\begin{abstract}
The stability of forest core areas is an important indicator of biotic diversity on a landscape level in the process of deciding whether certain forests could be cleared. Consequently, we decided to estimate the stability of forest core areas in Slovenia between 1975 and 2012, as we are in possession of sufficiently accurate data to make a comparison of forest cover for these 38 years.

Four types of changes in forest coverage (stable non-forest, deforestations, overgrowing and stable forest) are explained with an empiric model designed as a decision tree, which takes into account the altitude, the slope of the terrain, ground type, the distance of each cell on a raster map from the forest edge in the base year and the distance of each cell on a raster map from the nearest settlement in the base year. Explanatory models were built using the method of machine learning (Quinlan, 1986) using See5 (www.rulequest.com). The accuracy of the chosen model was 74.65\%. In 2012, stable forests covered $53 \%$ of Slovenia; their coverage has remained unchanged since 1975. From all the variables, land-use changes are best explained by the initial distance from the forest edge and partially by the slope of the terrain. The distance from settlements and the altitude, on the other hand, do not play a significant role.
\end{abstract}

Key words: stability of core area, persistent forests, Slovenia, land-use change

GDK 91:11(497.4)(045)=163.6 Prispelo / Received: 02. 04. 2014

Sprejeto / Accepted: 20. 08. 2014

\section{UVOD}

\section{INTRODUCTION}

Ohranjanje večjih sklenjenih površin naravnih habitatov je eden izmed možnih kriterijev za ocenjevanje biotske pestrosti (Alvey, 2006). Biotsko pestrost sicer zagotavljamo na genskem, vrstnem in ekosistemskem oziroma krajinskem nivoju. Na slednjem je pomembno, kako so v matici razporejeni krajinski gradniki, ki so nosilci pestrosti. Če velja, da je v naših razmerah v gozdni in gozdnati krajini matica gozd, pa je v kmetijski krajini to kmetijska raba. V obeh primerih je treba raziskati, kakšna je obstojnost gozdne matice, zaplat pa tudi koridorjev v času in prostoru, kateri so tisti deli gozdne maske, ki so obstali na svojem mestu od časov, ko je prostor preoblikovalo pretežno tradicionalno kmetijstvo, pa do najnovejših časov, ko prostor preoblikujemo predvsem z uporabo fosilne energije. Gozdovi so najbolj zreli kopenski ekosistemi, vendar je pot do zrelosti dolga, gozdovi potrebujejo mnogo let, da preidejo iz predzrelostnega stanja v zrelo stanje, slednje se po Odumu (1969) kaže v številnih kazalcih, omenimo vsaj visoke vrednosti neto proizvodnje, količine organske snovi, vrstne pestrosti in vrstne heterogenosti, notranje simbioze, pa tudi dobre zmožnosti ohranjanja hranil in odpornosti proti zunanjim motnjam. 
V Sloveniji narašča število posegov v gozdove, pretežno za kmetijske namene, čeprav je konec 20. stoletja zaznamovalo prekomerno opuščanje in zaraščanje kmetijskih površin (Kobler in sod,. 2005), ki se je sicer $\mathrm{v}$ zadnjem času ustavilo. $\mathrm{V}$ dosedanji metodologiji preverjanja možnosti za posege v gozd so težave povzročali ohlapno določeni kriteriji za presojo krčitev, to pa je oteževalo tako gozdarsko načrtovanje kot sodelovanje gozdarstva z drugimi uporabniki prostora (Pirnat, 2013).

Zato smo na podlagi tujih in domačih raziskav ter analize dosedanjih pristopov pri sodelovanju gozdarstva $v$ večnamenski rabi prostora zaznali glavne težave dosedanjih kriterijev za presojo krčitev gozdov. Na podlagi izsledkov tako predlagamo drugačna izhodišča pri odločanju o prihodnjih krčitvah gozdov v kmetijske in druge namene, ki pa mora temeljiti tudi na posodobljenem metodološkem pristopu za določanje krajinskih tipov (prim. Pirnat in sod., 2013).

Tako smo že predlagali poenostavitev dosedanjega sistema določanja funkcij gozda, določitev objektivnejših kazalcev za njihovo ocenjevanje in novo ovrednotenje funkcij s poudarkom na pestrostni funkciji posebej v kmetijski in primestni krajini. To poenostavitev smo tudi praktično pripravili $\mathrm{v}$ dosedanjem delu (Pirnat, 2007; Planinšek in Pirnat 2012a, b) in bi jo bilo mogoče ob spremembi zakonodaje že v veliki meri prenesti v vsakdanjo prakso.

Pri izbiri lokacije posegov v gozd bi morali upoštevati tudi sukcesijsko zrelost gozdov z visoko ohranjenostjo (drevesna sestava blizu naravni), ugodno zasnovo in z načrtno usmerjenimi preteklimi energijskimi in snovnimi vlaganji v nego in morebitno sanacijo (Pirnat in Hladnik, 2009).

Hkrati je pri načrtovanju sprememb rabe tal treba ohranjati dovolj velike površine sklenjenih gozdov z ohranjenimi jedri notranjega okolja in gozdove, ki zasedajo strateško pomembna mesta, ta pa omogočajo povezave z drugimi zaplatami oziroma gozdno matico in tako ustavarjajo ekološko omrežje oziroma krajinski vzorec (Forman in Collinge, 1997; Pirnat in Kobler, 2012; Hladnik in Pirnat, 2011).

Odprto vprašanje pa je ostalo, kako kot kriterij za presojo posegov vključiti tudi prostorsko in časovno stabilne gozdne površine, vključno z gozdnim robom, predvsem pa, kako lahko na podlagi dosedanjih sprememb rabe napovedujemo scenarije prihodnjega razvoja oziroma sprememb gozdnih površin; tega smo se zato lotili v pričujoči raziskavi z namenom, da bi tako zaokrožili kriterije, ki bi jih bilo treba upoštevati pred odločitvijo za krčitve gozdov.

\section{METODE DELA}

\section{METHODS}

Odločili smo se, da ocenimo stabilnost notranjega gozdnega okolja v Sloveniji med letoma 1975 in 2012, saj so nam na voljo primerljivo dovolj natančni podatki o gozdni maski za teh 38 let. Gozdno masko za leto 1975 smo pridobili iz topografske karte 1:50.000 iz leta 1981, rastrirano na $25 \mathrm{~m}$. Gozdno masko za leto 2012 predstavlja razred $2000 \mathrm{iz}$ baze kmetijske rabe tal MKGP z dne 10. septembra 2012, zaradi primerjave tudi rastrirana na $25 \mathrm{~m}$. Štiri vrste sprememb pokrovnosti z gozdom (stabilni negozd, krčitve, zaraščanje in stabilni gozd) pojasnjujemo z empiričnim modelom ( $\mathrm{v}$ obliki odločitvenega drevesa), ki upošteva naslednje ekološke in družbene vplivne dejavnike: nadmorska višina, naklon terena, oddaljenost vsake celice na rastrski karti od gozdnega roba v izhodiščnem letu, oddaljenost vsake celice na rastrski karti od najbližjega naselja v izhodiščnem letu. S prostorskim presekom nekdanje in sedanje maske gozdov smo izdelali karto, ki prikazuje štiri vrste sprememb v prostoru: stabilni negozd, krčitve, zaraščanje in stabilni gozd. Pojem zaraščanje opisuje $v$ našem primeru tako naravno zaraščanje kot ogozditev. Nato smo z empiričnim modelom povezali karto sprememb pokrovnosti z gozdom s kartami zgoraj naštetih ekoloških in družbenih dejavnikov, s katerimi smo želeli pojasniti spremembe gozdnatosti. Namen modela je bil razumevanje in pojasnjevanje povezav med spremembami gozdnatosti in vplivnimi faktorji. Vzorce za modeliranje smo izdelali takole: prešteli smo vse celice prostorskega rastra, posebej za vsako od štirih vrst sprememb, nato pa iz bolj zastopanih treh vrst sprememb slučajnostno vzorčili rastrske celice, tako da smo dobili približno enako število celic za vsako vrsto spremembe. Iz tega vzorca smo nato slučajnostno izbrali dva enako velika podvzorca. Enega smo uporabili za učenje (izdelavo, kalibracijo, ...) modela, drugega pa za ocenjevanje njegove natančnosti. Pojasnjevalne modele v obliki odločitvenih dreves smo na podlagi empiričnih učnih podatkov v prvi podmnožici rastrskih celic zgradili po metodi strojnega učenja (Quinlan, 1986) z orodjem See5 Release 2.02a (www. rulequest.com). Odločitveno drevo je hierarhično organizirana množica pravil v obliki IF-THEN, s katerimi model določa vrednost ciljne oziroma odvisne spremenljivke - v našem primeru spremembe gozdnatosti - na podlagi poljubne kombinacije vrednosti pojasnjevalnih oziroma neodvisnih spremenljivk. S spreminjanjem učnih parametrov orodja See5 (predvsem zahtevano najmanjše število primerov, ki naj ga pojasni vsako pravilo $\mathrm{v}$ odločitvenem drevesu) smo izdelali vrsto pojasnjevalnih modelov, ki se med seboj razliku- 
jejo po natančnosti napovedi, velikosti odločitvenega drevesa oziroma številu pravil, ki jih model vključuje. Na splošno rečeno večje odločitveno drevo zagotavlja boljšo napovedovalno natančnost modela, vendar ga je težje intuitivno razumeti in je zato manj uporabno za razlago pojava od manjšega drevesa. natančnost modelov smo ocenili na podlagi matrike napak, ki smo jo izračunali na podlagi neodvisnega vzorca. Preizkusili smo dve skupini modelov. Pri obeh skupinah modelov je bila enota vzorčenja rastrska celica oziroma piksel velikosti $25 \mathrm{~m}$. Slučajnostno so bili vzorčeni vsi piksli znotraj meje države s stopnjo vzorčenja $5 \%$. Napaka modela je bila ocenjena na enako velikem neodvisnem slučajnostnem vzorcu.

\subsection{Pojasnjevalni modeli}

\subsection{Explanatory models}

Prvo skupino modelov so sestavljali pojasnjevalni modeli na podlagi vzorčenja ne glede na deleže tipov sprememb v vzorcu.

Natančnost modelov je znašala med $86,3 \%$ in 88,5 \%, odvisno od pojasnjevalnih spremenljivk, vključenih v posameznih modelih. Modeli kažejo, da spremembe rabe najbolje pojasnjuje začetna oddaljenost od gozdnega roba. Oddaljenost od naselij in nadmorska višina nimata pomembnega vpliva. Pri takem načinu vzorčenja v modelu bolj prevladajo vplivi, ki jih je zaznati pri najbolj pogostem tipu sprememb (to je stabilen gozd), manj pa so v modelu pomembni vplivi, ki se pojavljajo pri krčitvah. Ker so modeli te skupine le deloma uporabni za razumevanje pojava, smo se odločili spremembo rabe tal razlagati z drugo skupino modelov, ki so jo sestavljali pojasnjevalni modeli na podlagi vzorčenja pikslov z uravnoteženjem frekvenc posameznih tipov sprememb v vzorcu. Stopnja slučajnostnega vzorčenja znotraj tako izbranih pikslov je bila zaradi manjše populacije pikslov povišana na $10 \%$. Natančnost modelov se je tokrat gibala med $40,9 \%$ do 75,3 \%, odvisno od spremenljivk, vključenih v posameznih modelih. Razmeroma nizka natančnost 40,9\% se je pojavila, ko smo iz nabora pojasnjevalnih spremenljivk izločili začetno razdaljo od gozdnega roba, ohranili pa začetno razdaljo do naselij, naklon terena in nadmorsko višino. Enako kot pri prvi skupini modelov tudi tu spremembo rabe najbolje pojasnjujeta začetna oddaljenost od gozdnega roba in deloma naklon terena. Oddaljenost od naselji in nadmorska višina nimata pomembnega vpliva.

Ob upoštevanju tudi razdalje do gozdnega roba pa so bile natančnosti modelov med 74,6 \% in 75,3\%.

Preizkusili smo tudi model, kjer smo upoštevali poleg omenjenih spremenljivk še talne tipe in razdalje do ceste. $V$ tem primeru je bila natančnost modela podobna, in sicer $75,0 \%$. Pri načinu vzorčenja z enako pogostostjo vseh tipov sprememb v vzorcu so vplivi vseh tipov sprememb enako močni, zato je zanesljivost napovedi manj odvisna od tipa napovedovane spremembe. Tak model je boljši za razumevanje pojava, manj dober pa je za napovedovanje pojava, ker je skupna natančnost modela nižja. Kot primer slika 1 kaže model, ki je rezultat učenja See5 s takimi učnimi parametri, ki zagotavljajo kompromis med jedrnatostjo (razumljivostjo) modela in njegovo napovedovalno natančnostjo. V učni vzorec pri tem poskusu nismo vključili pojasnjevalnih spremenljivk, ki se pri prejšnjih poskusih niso pokazale kot pomembne. To so razdalja do najbližje ceste, pripadnost regiji ter talni tip. Natančnost tega modela znaša $74,6 \%$. Spremembo rabe pojasnjuje $\mathrm{z}$ začetno razdaljo do gozdnega roba (ki je pozitivna zunaj gozda in negativna v gozdu) v metrih. Atribut sprememba rabe je enak ID spremembe, pojasnjen ob sliki zgoraj. Številke v oklepajih na koncu posameznih vrstic modela kažejo število učnih primerov v posameznem listu odločitvenega drevesa (prva številka) ter število napačno napovedanih primerov (druga številka).

Stopnja vzorčenja je $10 \%$. Učni vzorec vsebuje 422.772 pikslov, zastopanost vseh tipov sprememb rabe v učnem vzorcu je enaka. Učni parameter Pruning Confidence Level znaša $1 \%$ in se nanaša na intenzivnost obvejevanja dreves. Možni razpon vrednosti je $1 \%$ do $99 \%$. Majhne vrednosti vodijo k bolj intenzivnemu obvejevanju, torej nastane manjše odločitveno drevo. Najmanjše dovoljeno število pikslov oziroma

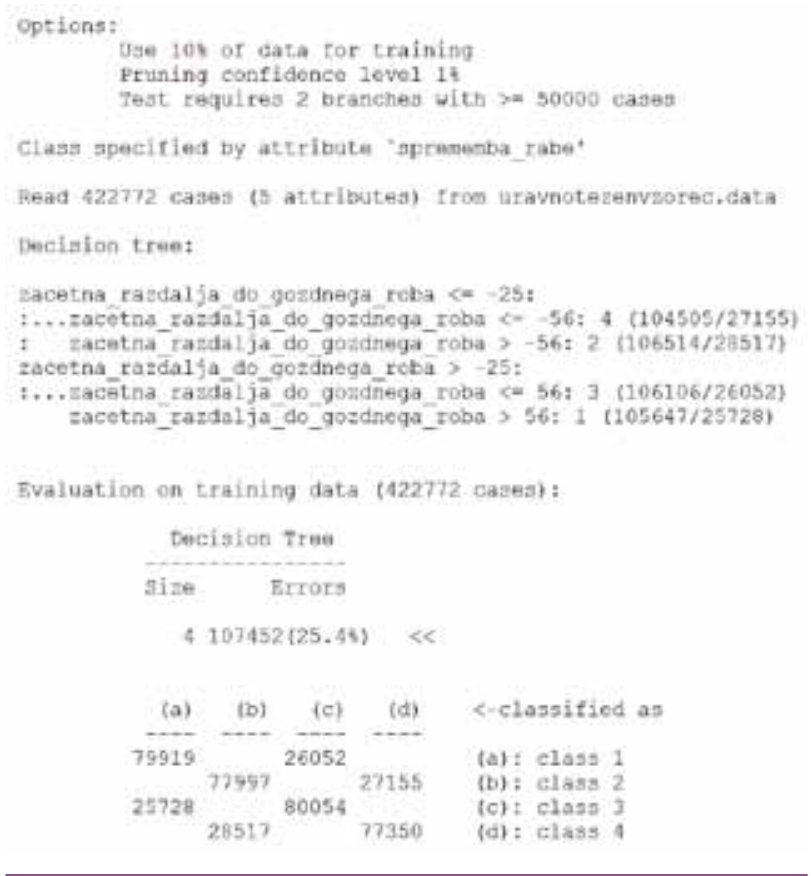

Slika 1: Rezultat učenja See5

Fig. 1: The result of studying See5 
primerov (cases) v vsakem listu drevesa je 50.000. Tipi sprememb rabe (classes) so označeni s kodami od 1 do 4 . Pomen kod je naslednji: 1 = trajen negozd, 2 = krčitev, 3 = zaraščanje, 4 = trajen gozd. Delež napak, izračunan iz prikazane matrike napak (ta temelji na neodvisnem testnem vzorcu), znaša $25,4 \%$, torej je napovedovalna natančnost modela enaka 74,6 \%. Oklepaji ob listih dreves vsebujejo po dve številki. Prva številka označuje število primerov (pikslov), na katere se pravilo v listu nanaša, druga pa število napačno klasificiranih primerov. Iz tega razmerja je mogoče izračunati oceno natančnosti vsakega lista (pravila) v odločitvenem drevesu posebej.

\section{REZULTATI}

\section{Results}

\subsection{Presek stanj 1975 / 2012}

3.1 Comparision of transitions in years 1975 / 2012

Kljub razmeroma veliki prostorski stabilnosti se pojavljajo po vsej Sloveniji vse vrste sprememb v gozdni maski, ki jih prikazujemo na sliki 2 in pojasnjujemo $\mathrm{v}$ preglednici 1 .

Kar 49,8 \% Slovenije pokrivajo stabilni gozdovi, torej sestoji, kjer sprememb rabe v obravnavanem obdobju ni bilo. Po drugi strani imamo 10,4 \% države, ki jo v letu 2012 pokrivajo novi gozdovi, medtem ko so bili na 3,3 \% države nekdanji gozdovi do danes izkrčeni.

Zaraščanje se je v tem obdobju pojavljalo bolj strnjeno predvsem $\mathrm{v}$ alpskem in $\mathrm{v}$ kraškem svetu, značilnost krčenj gozdov pa je, da se pojavljajo v sicer manjšem številu, a na večjih površinah. Res pa je, da gredo nekatere spremembe rabe na račun rahlega prostorskega zamika med kartama gozdov 1975 in 2012, kar je mogoče opaziti le pri večji povečavi presečne rastrske karte.

\section{RAZPRAVA}

\section{DISCUSSION}

Pri modelih na podlagi vzorčenja ne glede na deleže tipov sprememb v vzorcu se je pokazalo, da pri takem načinu vzorčenja $v$ modelu bolj prevladajo vplivi, ki se pojavljajo pri najbolj frekventnem tipu sprememb - našem primeru je to »stabilen gozd «, najmanj pa so pomembni vplivi na krčitve. Ti modeli kažejo, da spremembo rabe najbolje pojasnjuje začetna oddaljenost od gozdnega roba, pri enem modelu pa je kot pojasnjevalna spremenljivka udeležen tudi naklon terena. Oddaljenost od naselij in nadmorska višina nista imela opaznega vpliva. Že preprost model, ki napove le stabilen gozd ali stabilen negozd, obe vrsti sprememb pa »pozabi«, je imel prek 86-odstotno natančnost. Omenjeno visoko natančnost gre pripisati prevladujočemu deležu obeh stabilnih kategorij.

Pri modelih na podlagi vzorčenja $\mathrm{z}$ uravnoteženjem frekvenc posameznih tipov sprememb v vzorcu so vplivi vseh štirih tipov sprememb enako močni, zato je zanesljivost napovedovanja manj odvisna od tipa napovedovane spremembe. Tak model je boljši za razumevanje pojava, manj dober pa je za napovedovanje pojava, ker je nižja skupna natančnost modela. Podobno kot pri prvi skupini modelov tudi tu kaže, da spre-

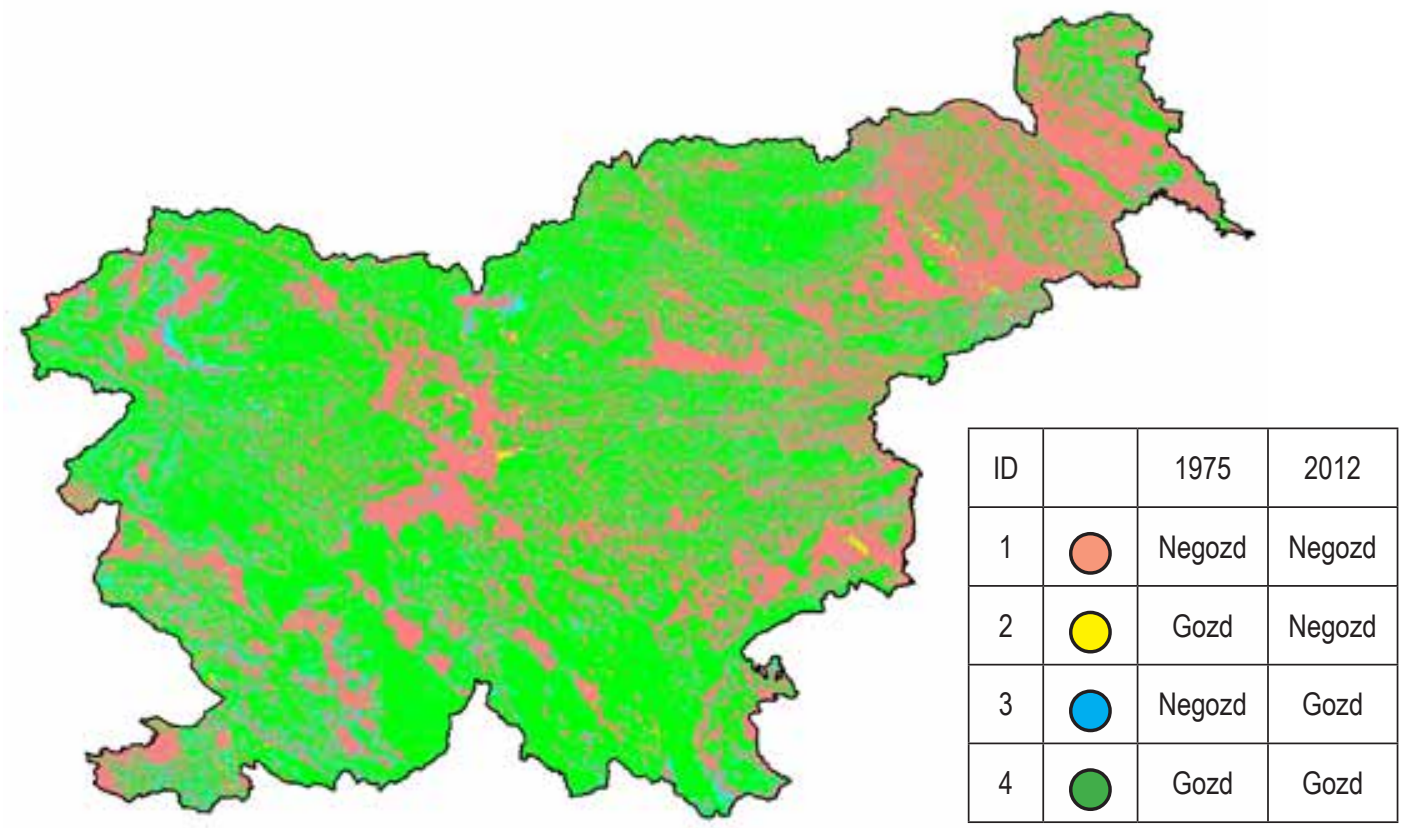

Slika 2: Presek stanj gozda 1975 / 2012

Fig. 2: The intersection of forest conditions in 1975 / 2012 
membo rabe najbolje pojasnjujeta začetna oddaljenost od gozdnega roba in deloma naklon terena. Oddaljenost od naselij in nadmorska višina nimata opaznega vpliva. Poskus, ko smo izločili oddaljenost od roba, da bi ugotavljali težo drugih spremenljivk, je potrdil, da je oddaljenost od gozda ključna spremenljivka, ostale tri spremenljivke pa ne pojasnjujejo kaj dosti, razmeroma nevplivna spremenljivka so bila tla. Hipotetična razlaga za to bi lahko bilo tudi veliko število talnih tipov. Morda bi se vpliv tal pokazal pri bolj grobi talni členitvi, na primer kras / dolomit / aluvij / magmatske kamnine. Seveda bi bile možne še druge pojasnjevalne spremenljivke, ki bi morda lahko izboljšale pojasnjevalno moč modela kot npr. gozdne združbe, tla, bližina prometnic, regionalizacija, dohodnina, ...

Model 4 spremenljivk na ravni vse države z natančnostjo 74,0 \% kaže, da naj bi čez 37 let kot stabilen gozd ostale vse gozdne površine, ki so zamaknjene bolj kot $56 \mathrm{~m}$ v notranjost gozda, seveda pri nespremenjenih okoliščinah, kot so veljale v obdobju 1975-2012.

Vsekakor moramo poudariti, da bi bilo na podlagi modela ter današnjega stanja uporabljenih pojasnjevalnih spremenljivk sicer možno napovedati prihodnje spremembe rabe, seveda pri nerealistični predpostavki, da okoliščine oziroma mehanizmi sprememb ostajajo ves čas enaki. Toda po drugi strani lahko pritrdimo Formanu in Collingejevi (1997), da »...prihodnost ni tisto, kar samo leži pred nami, ampak je nekaj, kar sami ustvarjamo...«

\section{ZAKLJUČKI}

\section{CONCLUSIONS}

Z idejo o gozdu kot življenjski skupnosti in širšemu razumevanje zgradbe in delovanja naravnih ekosistemov, kot ga je v drugi polovici 20. stoletja prispeval Naveh (2000), je tudi v gozdarstvu bilo mogoče vsaj premostiti razlike med tradicionalno usmerjenim gozdarstvom in področjem ohranjanja narave ter rastočimi socialnimi funkcijami gozdov. Sonaravno gozdarstvo je sprejeto kot model za razvoj krajinskega gozdarstva, usmerjenega $\mathrm{v}$ varstvo narave, ki bo podprt z mehanizmi ekosistemske stabilnosti (Debeljak, 2002; Johann, 2006). Če sledimo razmišljanju o sukcesijskem razvoju vegetacije, je mogoče sklepati, da so gozdovi najbolj razvit kopenski ekosistem, ki pa ga je človek tudi najbolj dolgotrajno spreminjal iz nekdanje pramatice. Gozdovi v srednji Evropi predstavljajo "pisavo«, s katero so ljudje vsakič znova zaznamovali spreminjajoči se evropski krajinski palimpsest. Tako poznamo gozdne krajine, $\mathrm{v}$ katerih je gozdna matica nepogrešljivi vzorec, ki zagotavlja primerno omrežje habitatov npr. velikim zverem, spet drugje, v gozdnatih in kmetijskih krajinah, pa bodo
Preglednica 1: Statistika preseka stanj gozda 1975/2012 Table 1: The statistics of the intersection of forest conditions in $1975 / 2012$

\begin{tabular}{|l|c|c|c|}
\hline Piksli (25m) & Negozd 1975 & Gozd 1975 & Skupaj 1975 \\
\hline Negozd 2012 & 11.869 .638 & 1.057 .391 & 12.927 .029 \\
\hline Gozd 2012 & 3.368 .083 & 16.141 .446 & 19.509 .529 \\
\hline Skupaj 2012 & 15.237 .721 & 17.198 .837 & 32.436 .558 \\
\hline
\end{tabular}

\begin{tabular}{|l|c|c|c|}
\hline Hektari & Negozd 1975 & Gozd 1975 & Skupaj 1975 \\
\hline Negozd 2012 & 741.852 & 66.087 & 807.939 \\
\hline Gozd 2012 & 210.505 & 1.008 .840 & 1.219 .346 \\
\hline Skupaj 2012 & 952.358 & 1.074 .927 & 2.027 .285 \\
\hline
\end{tabular}

\begin{tabular}{|l|c|c|c|}
\hline Procenti & Negozd 1975 & Gozd 1975 & Skupaj 1975 \\
\hline Negozd 2012 & 36,6 & 3,3 & 39,9 \\
\hline Gozd 2012 & 10,4 & 49,8 & 60,1 \\
\hline Skupaj 2012 & 47,0 & 53,0 & 100,0 \\
\hline
\end{tabular}

zaplate gozdov in drevesni koridorji delovali le kot stopni kamni v spremenjeni matici. Rudimente v krajini, ki jih lahko predstavljajo majhni ostanke naravne vegetacije (samotno drevo, ribnik ...) ali pa so odsev človekovega delovanja ter čustvovanja (stari mlin, kapelica $\mathrm{z}$ drevesom), lahko razumemo kot pomembne drobce, ki sestavljajo sliko nekdanjega človekovega odnosa do bivanja v določeni krajini. Kot taki predstavljajo še en nepogrešljiv vzorec - krajina in spomin (Schama, 1995).

Zaradi vsega tega želimo tudi s pomočjo predstavljenih modelov in dosedanjih raziskav (Firm in sod., 2013) povzeti zaključna priporočila v kriterije za odločanje pri prihodnjih krčitvah gozdov.

Gozdovi, ki bi jih praviloma ščitili pred krčitvami, naj bi izpolnjevali naslednje pogoje:

- V njih so po posodobljenih kriterijih na prvi stopnji določene nepremakljive funkcije gozdov, ki jim vsebinsko sledimo tako v gozdni matici, zaplati, koridorju ali rudimentu, slednje pridobijo pomen še posebej v krajinah z majhno gozdnatostjo. Pri iskanju objektivnih kriterijev se v največji možni meri opiramo na ugotovitve drugih strok (MKO, ARSO, ZRSVN...).

- Gozdovi, ki smo jih po načelih nege in varstva gozdov opredelili kot prednostne in smo zato vanje $\mathrm{v}$ preteklosti veliko vlagali $\mathrm{v}$ obliki umetnih snovnih in energijskih tokov.

- Gozdovi, ki imajo blizu naravno drevesno sestavo in so zreli. Zato so v njih v največji možni meri razviti mehanizmi ekosistemske stabilnosti. 
- Gozdovi, za katere smo ugotovili relativno stabilnost $\mathrm{v}$ času in prostoru, oziroma najdemo $\mathrm{v}$ njih stabilne predele nemotenega notranjega okolja, $\mathrm{z}$ veliko verjetnostjo izkazujejo primerne površine za zagotavljanje temeljnih ekoloških vlog (npr. pestrosti). Seveda je za te gozdove pomembna tudi visoka stopnja medsebojne prostorske povezanosti. Ob tem velja, da upravljanje biotske raznovrstnosti pogosto zahteva dovolj veliko kritično območje, hkrati pa bo vse bolj pogosto samo v krajinskem merilu realno mogoče izpolnjevati (pogosto diametralno nasprotne) zahteve različnih interesnih skupin. Gozdovi, ki izkazujejo prostorsko in časovno stabilnost, bodo ogrodje prihodnjih gozdnatih krajin in jih zato ne bi smeli prepuščati krčitvam. Samo krajine, kjer so različne zahteve enako dobro vpete $\mathrm{v}$ znanstveno presojo in v njej potrjene, si zaslužijo, da jih imenujemo kulturne krajine.

Sodobno gozdarstvo s tako razumljeno krajinsko razsežnostjo presega ujetost $\mathrm{v}$ meje gozda kot ekosistema. Če so ljudje te nekdanje meje oblikovali v preteklosti predvsem glede na potrebe kmetijstva, jih bodo v sedanjosti in prihodnosti vse močneje oblikovale potrebe urbane družbe in z njo povezane infrastrukture. Krajinsko gozdarstvo lahko štejemo kot stičišče klasičnega gozdarstva, ohranitvene biologije, krajinske ekologije in urbanega gozdarstva. Sonaravni gozdovi kot skelet za ohranjanje naravne podobe krajine so s svojo zgradbo in delovanjem osnova znanstvenemu razmišljanju in raziskovanju na področju ohranjanja narave in krajine v njej.

\section{POVZETEK}

Ohranjanje večjih sklenjenih površin naravnih habitatov je eden izmed možnih kriterijev za ocenjevanje biotske pestrosti. Biotsko pestrost zagotavljamo na genskem, vrstnem in ekosistemskem oziroma krajinskem nivoju. Na slednjem je pomembno, kako so v matici razporejeni krajinski gradniki, ki so nosilci pestrosti. Zanima nas, kakšna je obstojnost gozdne matice, zaplat pa tudi koridorjev v času in prostoru, kateri so tisti deli gozdne maske, ki so obstali na svojem mestu od časov, ko je prostor preoblikovalo kmetijstvo, ki ga je poganjala človeška in živalska energija, pa do najnovejših časov, ko ga oblikuje fosilna energija.

Prvobitnost gozdov in stabilnost njihovega notranjega okolja sta torej pomembna kazalca biotske pestrosti in drugih okoljskih funkcij gozdov na krajinskem nivoju. Stabilnost notranjega okolja je poleg nekaterih drugih kazalcev (zgradba, ohranjenost, negovanost, habitatna vloga) pomemben dejavnik, ko se odločamo o tem, ali bi določene gozdove lahko izkrčili z name- nom, da prepustimo določene gozdne površine drugi dejavnosti, npr. kmetijstvu. Zaradi tega smo se odločili, da ocenimo stabilnost notranjega gozdnega okolja $\mathrm{v}$ Sloveniji med letoma 1975 in 2012, saj so nam na voljo primerljivo dovolj natančni podatki o gozdni maski za teh 38 let. Gozdno masko za leto 1975 smo pridobili iz topografske karte 1:50.000 iz leta 1981. Gozdno masko za leto 2012 predstavlja razred 2000 iz baze kmetijske rabe tal MKGP z dne 10. septembra 2012.

Štiri vrste sprememb pokrovnosti z gozdom (stabilni negozd, krčitve, zaraščanje in stabilni gozd) pojasnjujemo z empiričnim modelom (v obliki odločitvenega drevesa), ki upošteva naslednje ekološke in družbene vplivne dejavnike: nadmorska višina, naklon terena, talni tip, oddaljenost vsake celice na rastrski karti od gozdnega roba $v$ izhodiščnem letu, oddaljenost vsake celice na rastrski karti od najbližjega naselja v izhodiščnem letu. Pojasnjevalne modele smo zgradili po metodi strojnega učenja (Quinlan, 1986) z orodjem See5 (www. rulequest.com). Natančnost izbranega modela je znašala 74,6 \%. Enota vzorčenja je rastrska celica (piksel) velikosti $25 \mathrm{~m}$. Slučajnostno izbrani so vsi piksli znotraj meja države, vendar tako, da se vsi tipi spremembe po frekvenci v vzorcu izenačijo s frekvenco pikslov krčenja (ki ga je površinsko najmanj). Stopnja vzorčenja znotraj tako izbranih pikslov je $10 \%$, izpeljana spet slučajnostno. Ocena napake modela je napravljena na enako velikem neodvisnem slučajnostnem vzorcu.

V letu 2012 so stabilni gozdovi, katerih površina se od leta 1975 ni spreminjala, pokrivali 53 \% Slovenije. Novi gozdovi, ki jih leta 1975 še nismo vključevali v gozdove, pokrivajo 10,4 \% države, površine nekdanjih gozdov, ki so bili do leta 2012 izkrčeni, predstavljajo 3,3 \% površine države. Zaraščanje se pojavlja predvsem v alpskem in v kraškem svetu, največji del krčitev najdemo $v$ manjšem številu večjih površin. Izmed vseh spremenljivk najbolje pojasnjujeta spremembo rabe začetna oddaljenost od gozdnega roba in deloma naklon terena. Oddaljenost od naselij in nadmorska višina nimata opaznega vpliva. Na podlagi modela ter današnjega stanja uporabljenih pojasnjevalnih spremenljivk bi bilo možno napovedati prihodnje spremembe rabe, seveda pri nerealistični predpostavki, da okoliščine sprememb ostajajo ves čas enaki. Model štirih spremenljivk na ravni cele države s točnostjo 74,0 \% kaže, da naj bi čez 37 let kot stabilen gozd ostale vse gozdne površine, ki so zamaknjene bolj kot $56 \mathrm{~m}$ v notranjost gozda (seveda pri nespremenjenih okoliščinah, kot so veljale v obdobju 1975-2012).

Tudi s pomočjo predstavljenih modelov želimo predlagati priporočila za odločanje pri prihodnjih krčitvah gozdov: 
Gozdovi, ki bi jih praviloma ščitili pred krčitvami, naj bi izpolnjevali naslednje pogoje:

- V njih so na prvi stopnji določene nepremakljive funkcije gozdov, ki jim vsebinsko sledimo tako v gozdni matici, zaplati, koridorju ali rudimentu, slednje pridobijo pomen še posebej v krajinah z majhno gozdnatostjo.

- Gozdovi, ki smo jih po načelih nege in varstva gozdov opredelili kot prednostne in smo zato vanje $\mathrm{v}$ preteklosti veliko vlagali v obliki umetnih snovnih in energijskih tokov.

- Gozdovi, ki imajo blizu naravno drevesno sestavo in so zreli, zato so v njih v največji možni meri razviti mehanizmi ekosistemske stabilnosti.

- Gozdovi, za katere smo ugotovili relativno stabilnost $\mathrm{v}$ času in prostoru, oziroma najdemo $\mathrm{v}$ njih stabilne predele nemotenega notranjega okolja, $\mathrm{z}$ veliko verjetnostjo izkazujejo primerne površine za zagotavljanje temeljnih ekoloških vlog (npr. pestrosti). Seveda je za te gozdove pomembna tudi visoka stopnja medsebojne prostorske povezanosti. Ob tem velja, da upravljanje biotske raznovrstnosti pogosto zahteva dovolj veliko kritično območje, hkrati pa bo vse bolj pogosto samo v krajinskem merilu realno mogoče izpolnjevati (pogosto diametralno nasprotne) zahteve različnih interesnih skupin. Gozdovi, ki izkazujejo prostorsko in časovno stabilnost, bodo ogrodje prihodnjih gozdnatih krajin in jih zato ne bi smeli prepuščati krčitvam. Menimo, da bi morali površine (maske) gozdov, ki izkazujejo trajno stabilnost $\mathrm{v}$ prostoru, obravnavati kot dokončne in jih, razen v izjemnih situacijah, ne bi predlagali za spremembo namembnosti.

\section{SUMMARY}

The preservation of large contiguous natural habitat areas is one of the possible criteria for the evaluation of biotic diversity. Biotic diversity is kept on the genetic, species and ecosystem or landscape levels. On the latter, the distribution of landscape elements as factors of variety in the matrix is of particular importance. We are interested in the sustainability of the forest matrix, patches and corridors in time and space, as well as which parts of the forest cover remained in their place from the time of agricultural landscape changes driven by human and animal energy up until modern times as the land is being shaped by fossil energy.

Thus, the persistent forests and the stability of their core area are important indicators of biotic diversity and other environmental forest functions on the landscape level. In addition to indicators such as structure, preservation, maintenance and habitat role, the stabil- ity of core area is an important factor in the process of deciding whether certain forests could be cleared in order for some forest areas to be used for other activities, for instance agriculture. Consequently, we decided to estimate the stability of forest core areas in Slovenia between 1975 and 2012, as we are in possession of sufficiently accurate data to make a comparison of forest cover for these 38 years. The forest cover for the year 1975 was analyzed based on a topography map $1: 50,000$ from 1981, while the forest cover for the year 2012 is represented by class 2000 from the database of agricultural land use provided by the Ministry of Agriculture, Forestry and Food on $10^{\text {th }}$ September 2012.

Four types of changes in forest coverage (stable non-forest, deforestations, overgrowing and stable forest) are explained with an empiric model designed as a decision tree, which takes into account the following ecologic and social factors of influence: the altitude, the slope of the terrain, ground type, the distance of each cell on a raster map from the forest edge in the base year and the distance of each cell on a raster map from the nearest settlement in the base year. Explanatory models were built using the method of machine learning (Quinlan, 1986) using See5 (www.rulequest. com). The accuracy of the chosen model was $74.6 \%$. The sample unit was a raster cell (pixel) measuring $25 \mathrm{~m}$. All the pixels within the country borders were chosen at random, yet so that all the change types according to the sample frequency were balanced by the frequency of the pixels of clearing (spatially least represented). The sampling rate within the pixels chosen in this way is $10 \%$ and it is again derived randomly. The estimation of model error was performed on an independent random sample of the same size.

In 2012, stable forests the coverage of which has remained unchanged since 1975 covered 53\% of Slovenia. New forests not yet included in 1975 cover 10.4\% of the country, while $3.3 \%$ belong to the areas of former forests cleared by 2012. Overgrowing is the most present in the Alpine and Karst regions, whereas most of the clearings appear in a small number of larger areas. From all the variables, land-use changes are best explained by the initial distance from the forest edge and partially by the slope of the terrain. The distance from settlements and the altitude, on the other hand, do not play a significant role. Based on the model and today's condition of the explanatory variables used it would be possible to predict future usage changes, of course only under an unrealistic assumption of the circumstances surrounding the changes remaining the same all the time. According to the four-variable, country-wide representative model with $74.0 \%$ accu- 
racy, all forest areas reaching farther than $56 \mathrm{~m}$ in the forest core would be considered a stable forest in 37 years (of course only under unchanged circumstances as present in the 1975-2012 period).

Based on the presented models, we would additionally like to propose recommendations for future decisions on forest clearings:

The forests in which clearings would generally not be allowed should meet the following conditions:

- Within the forests, the immovable forest functions have been determined on the first level and their contents are being traced in the forest matrix and the patch as well as in the corridor or rudiment. The latter grow in significance especially in the landscapes of low forest cover.

- The forests that were given priority based on the principles of forest maintenance and conservation and were therefore often subject to investments in form of artificial substances and energy inputs in the past. Forests with close-to-nature tree structure that have reached maturity and consequently possess the most developed mechanisms of ecosystem stability.

- The forests that were established as relatively stable in time and space or include stable parts of undisturbed core areas are very likely to provide suitable areas for the fulfilment of fundamental ecologic roles (e.g. diversity). Naturally, a high degree of mutual spatial connectivity is important for these forests as well. The managing of biotic diversity normally requires a large enough critical area, while at the same time it will increasingly often be possible to fulfil (frequently entirely opposite) demands of various interest groups only on a landscape scale. Forests displaying spatial and temporal stability will shape future forest landscapes and should therefore not be subject to clearings. In our opinion, forest surfaces displaying lasting spatial stability should be regarded as final and should, except in exceptional circumstances, not be proposed for the change of function.

\section{ZAHVALA}

\section{ACKNOWLEDGEMENTS}

Predstavljeno delo je nastalo v okviru projekta CRP V4 - 1144 "Kriteriji za presojo izvedbe krčitev gozdov", ki sta ga financirali Ministrstvo za kmetijstvo in okolje RS ter Javna agencija za raziskovalno dejavnost RS. Avtorja se zahvaljujeva tudi recenzentoma za koristne pripombe ter dopolnila.

\section{LITERATURA}

\section{REFERENCES}

Alvey A.A. 2006. Promoting and preserving biodiversity in the urban forest. Urban Forestry and Urban Greening, 5, 4: 195-201.

Debeljak M. 2002. Ekološko energijske značilnosti pragozda in gospodarskega gozda. Doktorska disertacija, Univerza v ljubljasni, Biotehniška fakulteta, Ljubljana: 217 str.

Firm D., Havliček, R., Kotnik A., Pirnat J. 2013. Možnosti za posodobitev kriterijev za presojo krčitev gozdov - uvod v razpravo. V: Pirnat J. (ur.).2013. Pogledi gozdarstva na krčitve gozdov : zbornik razširjenih povzetkov. 1. izd. Ljubljana: Biotehniška fakulteta, Oddelek za gozdarstvo in obnovljive gozdne vire: 41 - 43.

Forman R. T. T., Collinge S. K. 1997. Nature conserved in changing landscapes with and without spatial planning. Landscape and Urban Planning, 37: 129 - 135.

Hladnik D., Pirnat J. 2011. Urban forestry - linking naturalness and amenity = the case of Ljubljana, Slovenia. Urban Forestry and Urban Greening, 10, 2: 105-112.

Johann, E. 2006: Historical development of nature-based forestry in Central Europe. In: Diaci, J. (ed.) Nature-based forestry in Central Europe. Alternatives to Industrial Forestry and Strict Preservation. Studia Forestalia Slovenica Nr. 126.

Kobler A., Cunder T., Pirnat J. 2005. Modelling spontaneous afforestation in Postojna area, Slovenia. Journal for Nature Conservation, 13: 127-135.

Naveh Z. 2000: Introduction to the Theoretical Foundations of Multifunctional Landscapes and their Applications in Trandisciplinary Landscape Ecology. In: Brandt, J., Trees, B., Trees, G. (eds.) Multifunctional Landscapes. Interdisciplinary Approaches to Landscape Research and Management. Roskilde: 27 - 43.

Odum E., 1969. The strategy of ecosystem development. Science, 164: $262-270$.

Pirnat, J., 2007. Presoja kriterijev za določitev in ovrednotenje funkcij gozdov. Ljubljana: Biotehniška fakulteta, Oddelek za gozdarstvo in obnovljive gozdne vire. Mnsc: 28 str.

Pirnat, J., Hladnik, D., 2009. Umetni energijski vnosi in ohranjenost primestnih gozdov na Slovenskem. Zbornik gozdarstva in lesarstva 89: $67-77$.

Pirnat J., Kobler A. 2012. Landscape changes in the Pivka area, Slovenia. Zbornik gozdarstva in lesarstva, 98: 39 - 49.

Pirnat J. (ur.).2013. Pogledi gozdarstva na krčitve gozdov : zbornik razširjenih povzetkov. 1. izd. Ljubljana: Biotehniška fakulteta, Oddelek za gozdarstvo in obnovljive gozdne vire, 43 str.

Pirnat, J., Firm, D., Nastran, M. 2013. Kriteriji za presojo izvedbe krčitev gozdov : zaključno poročilo opravljenega raziskovalnega projekta v okviru Ciljnega raziskovalnega programa (CRP) »Zagotovimo.si hrano za jutri 2011-2020«. Ljubljana: Biotehniška fakulteta, Oddelek za gozdarstvo in obnovljive gozdne vire, 2013. 56, 7 str.

Planinšek Š., Pirnat J. 2012a. Predlog za izboljšanje sistema funkcij gozdov v Sloveniji. $=$ Proposals for improvement of the System of Forest Functions in Slovenia. Gozdarski vestnik, 70, 5-6: 276 $-283$.

Planinšek Š., Pirnat J. 2012b Zasnova meril in kazalnikov funkcij gozdov. $=$ Basis for Criteria and Indicators od Forest Functions. Gozdarski vestnik, 70, 9: 9 - 18.

Quinlan J. R. 1986. Induction of decision trees. Machine Learning, 1: 81-106.

Schama S. 1995. Landscape and Memory. Vintage books, New York: 647 str. 